\title{
A Risk Assessment Model Based On Attribute Theory
}

\author{
Jiali Feng \\ Information Engineering College, Shanghai Maritime University,1550,Address \\ Shanghai, 201306, China \\ Tao Sheng \\ Information Engineering College, Shanghai Maritime University,1550,Address \\ Shanghai, 201306, China \\ E-mail: Michaelsheng88@sina.com \\ www.shmtu.edu.cn
}

\begin{abstract}
Since the global financial crisis in 2008, the Chinese government has invested 4000 billion to maintain the economic growth. And the investment made the inflation became more seriously. However, the investment has led to high inflation rate. To fight inflation, it is important to understand the effects of changes in interest rates, which is itself a complicate issue. This article investigated the roles and the interrelationship of five main parties that involved in the issue using Attribute Theory method. These 5 main parts are Banks, Government, Enterprises, Domestic capital and International capital. Each of the 5 main parties was considered to consist of 5 attributes, including agriculture, construction, service, manufacturing and mining. In principle, these 5 main parties each directly play a role in the changes of interest rate, and, at the same time, affect each other. Here we used the Attribute Theory method to investigate how the five parties affect the interest rate and their impacts on each other. As a result, we built a mathematical model to provide guidance on determining the interest rates to properly deal with various economical issues.
\end{abstract}

Keywords: Qualitative theory; Interest rate; Economy

\section{Current Economic Situation}

Since the global financial crisis in 2008, the global economy has experienced serious depression. In China, during a considerably long time, the central bank has issued too much currency to the market that becomes one of the main problems in China economy and leads to serious inflation. Especially due to the price increase in staple commodities, the input inflation worsens the Chinese inflation. In July 2012, the CPI Consumer Price index rate reached $6.5 \%$, and kept running high until now. The high price of commodities lowers the living standard of Chinese people. Hence, the government has to adjust the price of commodities to release the pressure of inflation. National central bank, for example, the Federal Reserve (FED) can influence the inflation through adjusting interest rate as well as other currency policy. Raising the interest rate, as a typical method to control the inflation, will also leads to high unemployment rate and lowers production. Recently, the China, government tried to handle the inflation issue by increasing the Reserve Requirement and interest rate to withdraw the extra currency and slow down its negotiability. However, we have to realist inflation is not the only issue in Chinese economy. As a consequence of the financial crisis, Chinese government has invested 4000 billion in total to protect the local economies and markets. Till now, this policy combines with other local government investment has reach 15000 billion Yuan. In 2011, there is big demand to repay capital with interest. Rising interest rate will make the government facing higher pressure to repay the capital with interest. As a result, the government would encounter the risk of serious debt crisis, which has happened to Greece government. On the other hand, continuous rise of the interest rate will stop the enterprise from financing. In the worst case, this will result in bankruptcy of a great number of medium-and small sized enterprises. This in turn will cause a reduction in government tax income. . The data released by the State Administration of Taxation
in
2010
revealed 
that the national tax revenue reached 7739 billion Yuan, constituting $89 \%$ of the overall government revenue. Therefore, mass bankrupt of enterprises will seriously impact government income.

\section{Methods and Attribute Theory}

\subsection{The partial order category and Topes of attribute set}

Based on information received by the human brain, and can only feel the feeling of the property to respond to the fact that we made the human brain is deciphering the properties of things, and encode the information for the brain, so as to get the construction of thinking, the basic ideas and the formation of intelligence. We concluded that decipher the properties of object is the basic way for the brain to construct mechanism. At the same time we study the basic structure of the property set of things. Finally, we made a conclusion that: The Attribute Set of any object with level order between both attributes constructs a partial order category, and it with the conjuction becomes a Attribute Inference Lattice Category and a Monoid Category. They not only constitute the corresponding Topos respectively, but also there is representation model of an attribute baracentric coordinate system $\mathrm{K}^{(\mathrm{m})}(\mathrm{u})$ for for them. It is not only proved the mathematical description and discussion tool for the reasoning and the generation attribute based on conjuction between both attributes, but also using the functor categories, Topos and attribute coordinate system $\mathrm{K}^{(\mathrm{m})}(\mathrm{u})$.

Example: Let $\mathrm{x}(\mathrm{t}) \in \mathrm{X}$ be the borrower's income, $y(t) \in Y$ be the loans he need to repaid, $f$ is the function that describe the relationship between $\mathrm{x}$ and $\mathrm{y}, \mathrm{f}: \mathrm{X} \rightarrow \mathrm{Y}$. We will get $\mathrm{y}^{\prime} \in Y$ and $\mathrm{y}^{\prime}(\mathrm{t})=\mathrm{f}^{\prime}\left(\mathrm{x}^{\prime}(\mathrm{t})\right)$ to all $\mathrm{x}^{\prime} \in X$.

Let $x^{\prime}(t) \in X^{\prime}$ be the loans that can be repossessed by the bank, $y^{\prime}(t) \in Y^{\prime}$ be the bank's risk, $f$ is the function that describe the relationship between the $x^{\prime}(t)$ and $y^{\prime}(t)$, $\mathrm{f}^{\prime} \mathrm{X}^{\prime} \rightarrow \mathrm{Y}^{\prime}$, We will get $\mathrm{y}^{\prime} \in \mathrm{Y}^{\prime}$ and $\mathrm{y}^{\prime}(\mathrm{t})=\mathrm{f}^{\prime}\left(\mathrm{x}^{\prime}(\mathrm{t})\right){ }^{1}$

With the borrower and commercial bank as an example, as shown in Fig. 1 and the connection of the five deep attribute can be seen in Fig.2.

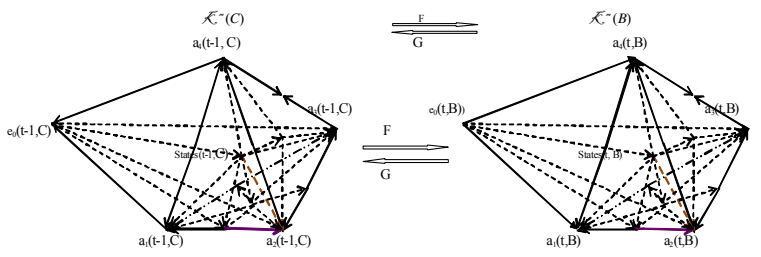

Fig.1. the attribute category between the borrower and the bank's loans ,the model that show the functor F and G (note: is the borrower's attribute category, $\mathrm{F}$ is the functor between them).

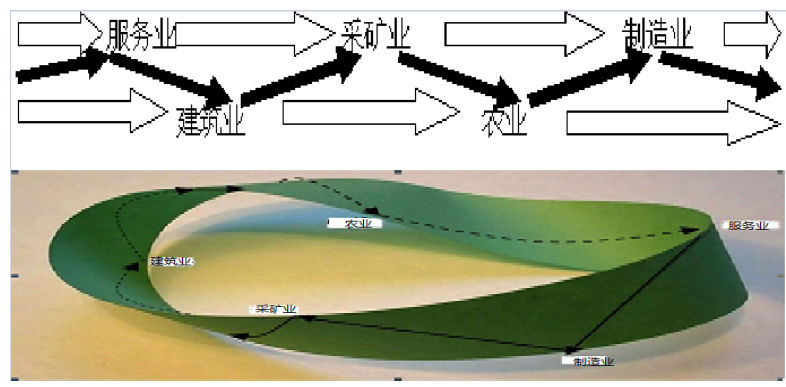

Fig.2. Möbius strip

\subsection{A attribute Topos consist of the category of functors Func(L(Au, S), S)}

We can see from the category theory that to any category $\mathrm{C}$, it will be a Topos by the dual category $\mathrm{C}^{\mathrm{op}}$ and the functor category Func $\left(C^{\text {op }}, S\right)$ of the set category $S$.

$L\left(A_{u}, \leq\right)$ is the dual category of the $L\left(A_{u}, \geq\right)$. If Func $\left(L\left(A_{u}, \leq\right), S\right)=\operatorname{Hom}\left(L\left(A_{u}, \leq\right), S\right)$, the $\operatorname{Func}\left(L\left(A_{u}, \leq\right), S\right)$ will be an attribute Topos.

In fact, as functor hom $(-, b) \in \operatorname{Hom}\left(L\left(A_{u}, \leq\right), S\right)$,so, not only $\operatorname{hom}(-, b)$ can be seen as a functor from functor category Func $\left(\mathrm{L}\left(\mathrm{A}_{\mathrm{u}}, \leq\right), \mathrm{S}\right)$ itself, but also attribute Topos Func $\left(L\left(A_{u}, \leq\right), S\right)$ can be seen as category, its object is the hom-set of the hom(-,b).It will be the state shot with two functor natural transformation $\tau: \operatorname{hom}(-, a) \rightarrow \operatorname{hom}(-, b)$ between two functors.

The attribute Topos Func $\left(\mathrm{L}\left(\mathrm{A}_{\mathrm{u}}, \leq\right), \mathrm{S}\right)$ have the key properties:

Assume that $a$ is the top attribute of $\mathrm{L}\left(\mathrm{A}_{\mathrm{u}}, \geq\right)$, then $a$ will be the bottom attribue of $L\left(A_{u}, \leq\right)$, so it can be the final object $1 u$ of Func $\left(L\left(A_{u}, \leq\right), S\right)$. If $a$ is the performance properties of $b$, that is we have a state shot $\mathrm{f}: \mathrm{a} \rightarrow \mathrm{b}$ in $\mathrm{L}\left(\mathrm{A}_{\mathrm{u}}, \geq\right)$. It induces a synthesis of partial order $\mathrm{S}_{\mathrm{a}}=\left\{\mathrm{f}_{\mathrm{n}}=\mathrm{g} \cdot \mathrm{f} \mid \mathrm{f}_{\mathrm{n}}: \mathrm{c}_{\mathrm{n}} \rightarrow \mathrm{a}\right\}$ in $\operatorname{Func}\left(\mathrm{L}\left(\mathrm{A}_{\mathrm{u}}, \leq\right), \mathrm{S}\right)$, as shown in Fig.3, which is called the Sieve screen or filter with the target $a$. To the attribute of the partial order $A_{u}$ or category $L\left(A_{u}, \leq\right)$, because all the synthesis partial order $f_{n}$ is the arrow $f_{n}$ from different attributes $c_{n}$ to the top attribute or final object $a, S_{a}$ is the cluster of the partial order $\mathrm{f}_{\mathrm{n}}$ which is the way from $\mathrm{c}_{\mathrm{a}}$ to $a$. As shown in Fig.4, they are not only constitute a pullback but also exist a limit.

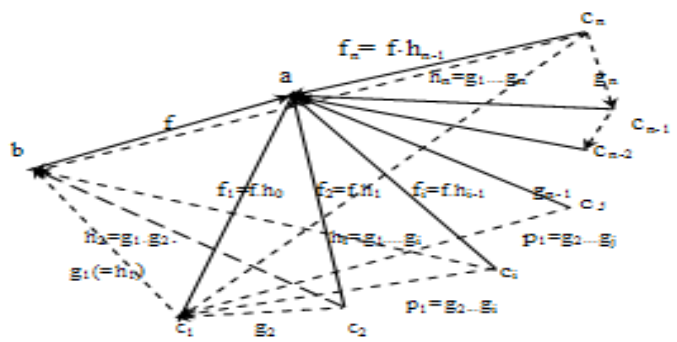

Fig.3. The Sieve Sa, Sb, S1 consist of $\{\mathrm{fi}\},\{\mathrm{hj}\}$ and $\{\mathrm{pj}\}$. 


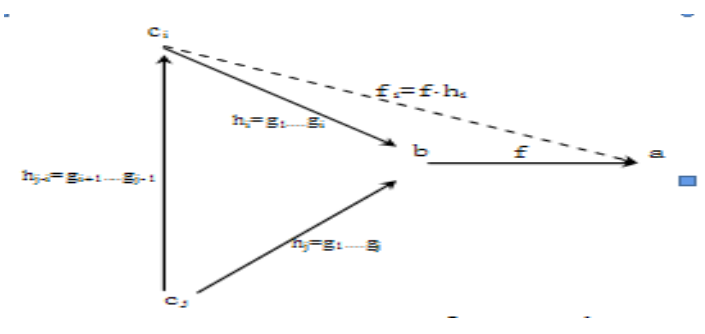

Fig.4. The limit Lim ci $=$ b of Sieve Sa

\section{Model for the Relationship of Bank Interest Rate and China Economy}

This model was developed to investigate the role and interrelationship of 5 main parties: Bank, Government, Enterprise, Domestic and International capital.

In addition to the 5 main parts, we introduce another two variable, time dimension and fundamental economy. The ranges of interest rate studied are four Sets $:(10 \% \sim 8 \%) 、(8 \% \sim 6 \%) 、(6 \% \sim 4 \%) 、 \quad$ (under $4 \%$ We provide each of themthe bank interest, a different weight which represent its effects in real economic situation. ${ }^{2}$ Furthermore, we also see that interest rate impact the economy slowly and usually accumulate in a long run. Hence we should not only concern the impact of an interest rate to the inflation when it is set, but also consider the effect of accumulation in the future. Time dimension has the unit of Year.. Then using the model to work out how the interest rate in this year can influent the coming years. Meanwhile, different fundamental economy behaves differently in different interest rate situation. Here we set 3 fundamental economy: Inflation (set to 1), Normal (set to 2), Deflation (set to 3). We are aware that same economic behaviors have very different result in these 3 situations. Here we try to give a proper weight to the 3 fundamental economy in order to simulate the real world economic behavior. ${ }^{3}$

Above all, based on our analysis of all the main parts and dimensions, we built the mathematics model from macroscope to microscope, and from entirety to parts.
Table 1 represent the condition ("represent sth" add object here) when only considering 1 year interest rate impact on various economy situation.

In this case, we need to analyze in deep. Table 3 describes in normal economy, how overall macroscopic economy behave when interest rate changes. We can find the reasons by analyzing the through the table.

Table 2 describes in normal economy, how the 5 main parts behave when interest rate change. However, in inflation or deflation, we should not only consider the effect of interest rate, but also add proper weight. For example, interest rate of $4 \%$ in normal economic situation should benefit to domestic capital. But in inflation case, $4 \%$ interest rate will promote capital circulate and exacerbate the inflation. That will badly impact other main parts. ${ }^{4}$

Through the analysis of Table 2, we understand that each main partier's behavior toward the change of interest rate in deep is judged by their interactions. All of them impact each other. And the accumulation of the impact represents real world's behavior in certain interest rate. The relationship table below represents typical ways that they impact each other. Certainly, we have to consider the economic situation, (Foreign hot money is sensitive to the interest rate and exchange rate, in short is the high interest rates will infux and low interest rates will flow out. So the article will not calculation specific but it needs to be considered.) $)^{3}$ as shown in Table 3.

Meanwhile, we should realize that economy is not a shorter process. We should not only concentrate on the effects of interest rate changes in short time but also consider its influence to future economy. Of course, the longer the accumulation time, the smaller its effects. $S$ represents the impact and trepresent the time. ${ }^{5}$

$$
S=X t / t
$$

And obviously, a certain weight should be adopted in different fundamental economy.

Table 1. Year interest rate impact on various economy situation

\begin{tabular}{|l|l|l|l|}
\hline & \multicolumn{1}{|c|}{ Deflation } & \multicolumn{1}{|c|}{ Normal } & \multicolumn{1}{|c|}{ Inflation } \\
\hline $\begin{array}{l}\text { Interest rates ( } \\
10 \% \sim 8 \%)\end{array}$ & $\begin{array}{l}\text { It would be devastating if we } \\
\text { take a high interest rates under } \\
\text { Deflation. }\end{array}$ & $\begin{array}{l}\text { If we take a high interest rates for a } \\
\text { long time, may be it would cause } \\
\text { deflation. }\end{array}$ & $\begin{array}{l}\text { It is benefit to the overall economy and will } \\
\text { help reduce the economic mobility }\end{array}$ \\
\hline $\begin{array}{l}\text { Interest rates ( } \\
8 \% \sim 6 \%)\end{array}$ & $\begin{array}{l}\text { It would be adverse to the } \\
\text { overall economy and will } \\
\text { aggravating inflation. }\end{array}$ & $\begin{array}{l}\text { It would increase the uncertainty to } \\
\text { the economy and likely to cause } \\
\text { deflation. }\end{array}$ & It would help to ease high liquidity \\
\hline $\begin{array}{l}\text { Interest rates ( } \\
6 \% \sim 4 \%)\end{array}$ & $\begin{array}{l}\text { A littlt higher interest rates } \\
\text { would be a block for the } \\
\text { economy turn back to normal. }\end{array}$ & $\begin{array}{l}\text { The interest rates has both } \\
\text { advantages and disadvantages. }\end{array}$ & $\begin{array}{l}\text { It would be adverse to the overall economy and } \\
\text { will make the inflation to be more serious }\end{array}$ \\
\hline $\begin{array}{l}\text { Interest rates ( } \\
\text { under 4\%) }\end{array}$ & $\begin{array}{l}\text { It would be beneficial to the } \\
\text { economy and will increase the } \\
\text { domestic liquidity. }\end{array}$ & $\begin{array}{l}\text { Low interest rates is good for } \\
\text { economic development,we suggest } \\
\text { to maintain. }\end{array}$ & $\begin{array}{l}\text { It would be devastating if we take a low } \\
\text { interest rates under Inflation }\end{array}$ \\
\hline
\end{tabular}


Table 2. The 5 main parts' reaction in interest rate change

\begin{tabular}{|c|c|c|c|c|}
\hline & Interest rates $(50 \% \sim 30 \%)$ & Interest rates $(30 \% \sim 20 \%)$ & Interest rates $(20 \% \sim 10 \%)$ & Interest rates (under $10 \%$ ) \\
\hline Government & $\begin{array}{l}\text { The revenue of the } \\
\text { government have an } \\
\text { significanty decrease and } \\
\text { expenditure increased } \\
\text { significanty which will } \\
\text { increase the risk. }\end{array}$ & $\begin{array}{l}\text { The government's revenue } \\
\text { decreased and expenditure } \\
\text { increased }\end{array}$ & $\begin{array}{l}\text { The revenue of the } \\
\text { government have an slight } \\
\text { decrease and expenditure } \\
\text { increased }\end{array}$ & $\begin{array}{l}\text { The revenue of the } \\
\text { government increase and } \\
\text { expenditure decreased }\end{array}$ \\
\hline Bank & $\begin{array}{l}\text { The bank's revenue } \\
\text { decreased significanty and } \\
\text { defaults increased(equals to } \\
\text { expenditure) which increase } \\
\text { the risk }\end{array}$ & $\begin{array}{lr}\text { The bank's } & \text { revenue } \\
\text { decreased and } & \text { defaults } \\
\text { increased(equals } & \text { to } \\
\text { expenditure) } & \end{array}$ & $\begin{array}{l}\text { The bank's revenue } \\
\text { increased slightly and } \\
\text { defaults decreased(equals to } \\
\text { expenditure) }\end{array}$ & $\begin{array}{lr}\text { The bank's } & \text { revenue } \\
\text { increased and } & \text { defaults } \\
\text { decreased(equals } & \text { to } \\
\text { expenditure) } & \end{array}$ \\
\hline Enterprise & $\begin{array}{l}\text { The enterprise faces a } \\
\text { serious problem of cash flow } \\
\text { and circulation of goods } \\
\text { slow down. }\end{array}$ & $\begin{array}{l}\text { The enterprise faces a } \\
\text { problem of cash flow and } \\
\text { circulation of goods slow } \\
\text { down. }\end{array}$ & $\begin{array}{l}\text { The enterprise faces a little } \\
\text { problem of cash flow and } \\
\text { circulation of goods } \\
\text { improve slightly. }\end{array}$ & $\begin{array}{l}\text { The enterprise have a good } \\
\text { cash flow and smooth } \\
\text { circulation of goods }\end{array}$ \\
\hline $\begin{array}{l}\text { Domestic } \\
\text { financial }\end{array}$ & $\begin{array}{l}\text { The liquidity of the domestic } \\
\text { capital declined obviously } \\
\text { and overall economy } \\
\text { become weak }\end{array}$ & $\begin{array}{l}\text { The liquidity of the domestic } \\
\text { capital declined and overall } \\
\text { economy become weak }\end{array}$ & $\begin{array}{l}\text { The liquidity of the } \\
\text { domestic capital declined } \\
\text { slightly and have a slightly } \\
\text { adverse effect on overall } \\
\text { economy }\end{array}$ & $\begin{array}{l}\text { It is good for overall } \\
\text { economy and the circulation } \\
\text { of the domestic captial. }\end{array}$ \\
\hline $\begin{array}{l}\text { Foreign hot } \\
\text { money }\end{array}$ & $\begin{array}{l}\text { The foreign hot money pour } \\
\text { into and will have an impact } \\
\text { to the domestic financial. }\end{array}$ & $\begin{array}{l}\text { The foreign hot money pour } \\
\text { into }\end{array}$ & $\begin{array}{l}\text { The foreign hot money have } \\
\text { little desire to get in. }\end{array}$ & $\begin{array}{l}\text { The foreign hot money have } \\
\text { little desire to get in. }\end{array}$ \\
\hline
\end{tabular}

Table 3. the deep impact between 5 main parts

$$
\text { Govermant } \begin{gathered}
\text { The government borrow from bank and repay capital with interest, etc } \\
\text { TThe government gain financial income from enterprise, etc } \\
\text { The government gain financial income from domestic capital, etc }
\end{gathered}
$$

Bank $\left\{\begin{array}{l}\text { ZBank lending to govermm ent to get the benefits and take the chance of bad loans, etc } \\ \text {-Bank lending to enteprise to get the benefits and take the chance of bad loans, etc } \\ \text { ZDomestic cantial deposit and get a loan from the bank and the bad loans mav occur etc }\end{array}\right.$

Entegprisas $\begin{gathered}\text {-Enterprise have the financial support from the government, etc } \\ \text {-Enterprise get bank loans, etc } \\ \text {-Enterprise products sold in domestic captial and get folk loans etc }\end{gathered}$

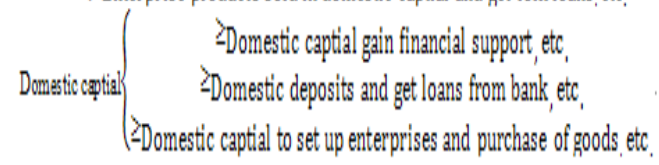

After realize the relationship of all the main parts, the mathematics model can be achieved by JAVA. Fig.5 shows the simulation results.

Fig.5 describes the experiment result in time dimension $\mathrm{T}=3$ (year), and deflation environment. Interest rate in first year is $2.6 \%$, second year is $6.8 \%$, and the third year is $2.2 \%$. We assumed all the economic parts can process properly in the range of $[0,100]$. The lower of the score, the less dangerous it is. If exceed 100, it means the main part is in danger. From picture 1, we see that in deflation environment, keep the low interest rate in 3 years, the overall economy can maintain a smooth progress, and in low risk.

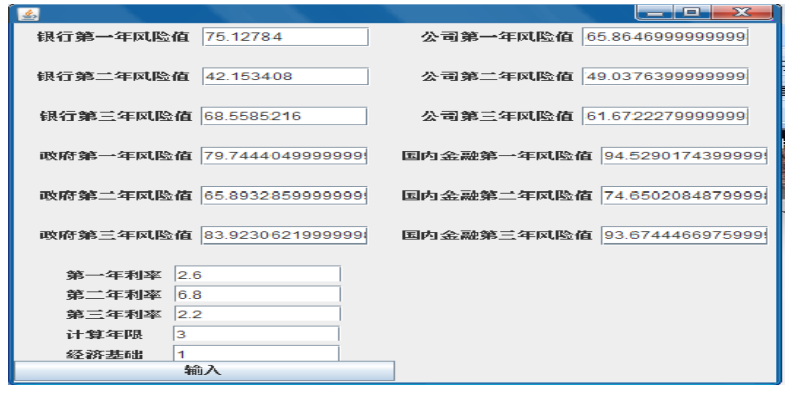

Fig.5. Result in the rate $(2.6 \%, 6.8 \%, 2.2 \%)$

Same precondition, let's adjust the interest rate as $7.1 \%$ in first year and $6.6 \%$ in second year, $6.0 \%$ in the third year. Then we can get the result shown as Fig.6:

Obviously we see that under a high interest rate, the accumulation effect is very clear. All the main parts are facing the risk of break up. Overall risk value also exceeds the preset 100 . It correctly represents the requirement of interest rate in different economy situation.

After the basic model we also want to build is a model that can show the instant contact of the five parts, so, we use the NEATBEANS IDE 6.9.1 to build out a real-time visual program as shown in the Fig. 7.

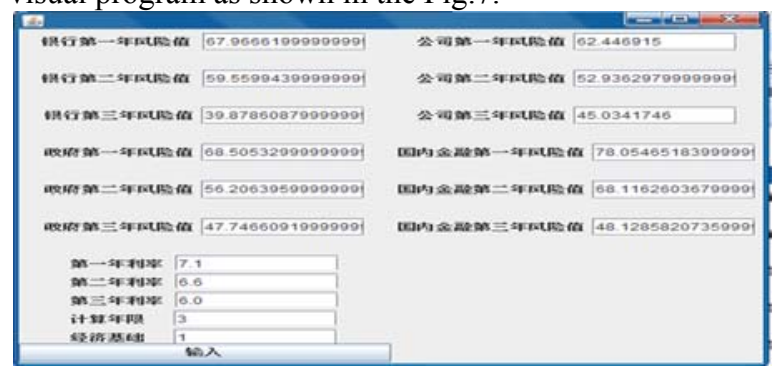

Fig.6. Result in the rate $(7.1 \%, 6.6 \%, 6.0 \%)$

Published by Atlantis Press

Copyright: the authors 


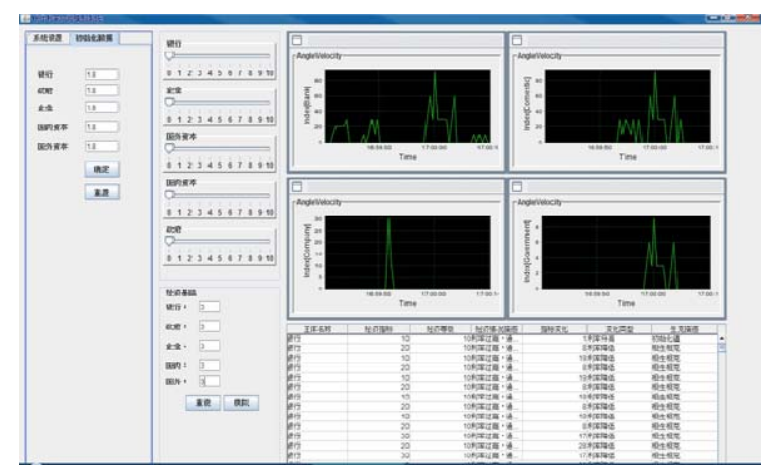

Fig.7. Real-time demonstration figure

\section{Conclusion}

To sum up, this article built a mathematics model for the 5 main parts and their relationship based on Qualitative theory method, correctly represents how these main parts behave and their impacts on each other in different interest rates, and properly estimates the risk value for these main parts. The relationship functions provided in this article was based on various related papers, which would require further practice. Next, I will work on the relationship functions as well as the weights in order to make it represent closely to real world economy, and let the model work properly.

\section{Acknowledgements}

We thank for Jingjuan Feng, Ph.D Candidate of US Berkeley, for her help in English transformation.

\section{References}

1. Jiali Feng, Qualitative Mapping Orthogonal System Induced by Subdivision Transformation of Qualitative, Criterion and Biomimetic Pattern Recognition, Chinese journal of electronics, Special Issue on Biomimetic Pattern Recognition, 85 (6A), (2006).

2. H. B. Malmgren, The Credit Crisis is not Over, The International Eeonomy, (2007): 58-61.

3. (Switzerland) Manuel Oman, credit risk assessment, Yang Yuming Beijing: Tsinghua University Press, (2004).

4. Vasicek, O: An Equilibrium Characterization of the Term Structure of Interest Rates, Journal of Financial Economics, 01(5) (1977): 177-188.

5. Lihu Wang, Jiali Feng. Classifying and learning based on qualitative mapping, Proceedings International Conference on Intelligent Information Technology, (2002): 559563. 